\title{
An Anthropology of Belief and a Theory of Homo Religiosus
}

L'anthropologie de la croyance et la théorie de l'homo religiosus

Antropología del creer y teoría del homo religiosus

\section{Albert Piette}

\section{(2) OpenEdition}

\section{Journals}

Electronic version

URL: http://journals.openedition.org/assr/26216

DOI: $10.4000 /$ assr.26216

ISSN: $1777-5825$

Publisher

Éditions de l'EHESS

Printed version

Date of publication: 20 October 2014

Number of pages: $277-294$

ISBN: 978-2-7132-2433-1

ISSN: 0335-5985

\section{Electronic reference}

Albert Piette, "An Anthropology of Belief and a Theory of Homo Religiosus », Archives de sciences sociales des religions [Online], 167 | juillet-septembre 2014, Online since 20 October 2017, connection on 20 April 2019. URL : http://journals.openedition.org/assr/26216 ; DOI : 10.4000/assr.26216 


\section{Albert Piette}

\section{An Anthropology of Belief and a Theory of Homo Religiosus}

In the social sciences of religion, the temptation to over-interpret jeopardises the description and analysis of religious beliefs, or more specifically modes of belief. Sometimes these are understood - implicitly - as indications of exoticism, or deviations from a rational norm needing to be explained by sociocultural factors. At other times, the reorganisation of belief systems (for example indicative of either belonging without adhering to content or adhering without belonging) is considered a significant sign of the contemporary evolution of religion. Thus beliefs are often treated as synonymous with homogeneous, shared cultural representations, as if adherence, acceptance and the mode of belief were selfevident ${ }^{1}$.

Believing in a non verifiable statement, thinking that incredible things exist: this is one of Homo Sapiens' specificities (A. Piette, 2013). But what does the act of believing consist of? How can we characterise this moment of adherence to religious statements? Half-believing, believing contradictory things, sceptical believing, floating between wonder and credulity, being able to change "programs of truth", hesitating or remaining indifferent when facing the choice between truth or fiction: herein is the multiplicity of attitudes and modalities of belief that Paul Veyne highlighted brilliantly in his analysis of Greek myths (P. Veyne, 1988 [1983]). From this diversity, Jon Elster summarised three contradictory belief types operating in peaceful coexistence: those belonging to different sets of data, one of which trumps the other when they meet (the child who believes that hot water comes from a tank in the basement while also believing that water it is carried into the house by two underground pipes, one for cold and one for hot); those that coexist with regard to the same object but follow different modalities (the Romans who created a cult around their divinised emperor, but did not address him for serious matters); those that coexist within one and the same idea (the knowledge of the natural destiny of a corpse and the human inability to think through one's own annihilation) (J. Elster, 1993: chapter 1).

1. This text has been translated by Matthew Cunningham. 
It is therefore a matter of setting aside the usual image of people adhering to beliefs either in conformity with or in spite of those instituted by society, being conscious and logical within themselves, always being serious in the actions they perform, and therefore always being over-interpreted in relation to events they most often experience simply and mundanely. The point is not to replace this with the image of unbelieving, unconscious, inconsistent people who lack serious action, but rather that of people who believe without believing (J. Mair, 2012).

Large-scale ethnographic study, in association with the notion of culture, runs the risk of disregarding individual differences, which are overshadowed by the cultural representations thus collated. Matching an individual's beliefs with representations that are public, pervasive or orthodoxly organised, and linking these to the coherence of a singular cultural entity distracts attention from concrete behaviours and actions. This is not only to ignore individual variations but also to assume that individuals have full access to entirely transparent representations. This is to forget the vague and sometimes ephemeral dimension of acts of believing.

A phenomenographic approach focused on particular variations, individual expressions and isolated moments is needed if one is to get closer to modes of belief ${ }^{2}$. This article must be read as a consideration of "what goes on" when someone is believing. It aims to present theoretical reference points with a view to establishing an anthropology of hesitant and fragmentary modalities of belief. The examples provided are drawn mainly from a study of Catholic parishes in France. The close observation of liturgy and various meetings between parishioners on the one hand and personal interviews on the other enabled me to obtain the data that follows (A. Piette, 1999 et 2003).

\section{Religious statements}

"Jesus is alive." "The spirit of the Lord is present among us." These are the statements one usually hears in Catholic religious ceremonies. They have at least three characteristics (P. Boyer, 1994). They contradict the intuitive expectations and ordinary anticipations of individuals, such as when they attribute the quality "alive" to a person who is known to be dead. They are composed of notions or concepts that have a certain complexity for those who utter them - the "believers" themselves - and are vague in meaning (such as the notion of spirit, the idea of presence, and many others), making them sources of doubtful interpretations and persistent controversies. Finally, they do not imply - again, for the "believers" themselves - a necessary link to other statements or behaviours that would seem to follow logically and directly from them. Would any Catholic

2. See the commentary of Lamine (2008) and the analysis of Luca (2013a and 2013b). 
asserting Christ's "real presence" be prepared to search for physical traces of this? Dan Sperber uses the term "semi-propositional" to describe the contents of a mental representation that is incompletely established (D. Sperber, 1985 [1982]: 71). The believer does not fully pursue the propositional logic by which a representation identifies one and only one proposition. Since it opens an array of interpretations that might clarify this content (without there being any single "right" interpretation), semi-propositional representations allow a kind of loosening in face of vague contents (ibid.: 71-73). The individual does not receive this semipropositional content as a fact but as a representation that involves a certain mental vagueness, which does not prevent him or her from having confidence in both the authority that issues the statement and the orthodoxy of its representation.

Indeed it is quite the contrary; the "mysteries" that are beliefs, often recognised as such by the "natives", are preserved and transmitted by virtue of the trust accorded to the source of these statements. This gives good reason to believe despite the uncertainty and doubt that these statements arouse. Although the French verb "croire" points to this internal contradiction (M. Ruel, 1982), where an assertion coexists alongside that which impedes the propositional advancement of its contents, we would like in what follows to emphasise a mode of experience that is not necessarily associated with this lexical usage. Every act of believing, whatever its nature, is linked to cognitive vagueness. Take for example, the remarkable mind map (which can be interpreted as a set of semi-propositional representations) of an octogenarian who subscribes to the idea of the immortality of the soul but wishes to delay Heaven as long as possible, while at the same time desiring to live on in the memory of his descendants, and ask in addition that his loved ones place a valued object in his final resting place, and that they do not forget to look after his grave. From this Paul Veyne extracts the following meanings: "one believes in Heaven, one is afraid of being a corpse, one feels one's future death will be a kind of sleep, one does not want to be neglected or forgotten like a dog” (P. Veyne, 1992 [1976]: 249). According to Veyne, “only the first of these four modalities is influenced by religious beliefs; but, even in a population that believes in the Resurrection, the three other experiences persist". He explains: "it would be a mistake to believe that religion is coextensive to culture; some attitudes to the beyond vary according to beliefs, but only some; faith in personal immortality did not prevent Christians from also wanting to survive in their descendants..." (P. Veyne, 1992 [1976]: 247-249). Someone slides a few photos into a coffin just before it is closed. He or she knows that the corpse will not be able to use these objects but offers them anyway... At the moment of the gesture, it is impossible to strengthen this act of believing mentally without at the same time summoning one's critical knowledge. The individual prefers to keep his or her semi-propositional representations below the level of consciousness; this is the minimal internalisation that makes it possible to manage the incompatibilities in this case. It is as if he or she perceives a "risk" in taking the reflexion further. 
The contents of beliefs refer to sources of different types. The origin of a semi-propositional statement can be the ultimate authority of an institution (the church for example), which, as Michel de Certeau has said, has the ability to refine and control a coherent doctrine and link members to a common affiliation (M. de Certeau, 1981: 381). But the institutional guarantee can be set aside and replaced by a voice of scepticism or critical attitude (one's own or that of others), leading to selectiveness with regard to what is worth believing. Once a few fabulous details and far-fetched fantasies have been ousted, the believer can retain a kind of essential core of the church's dogmas. Semi-propositional statements can be disconnected even more easily from institutional authority and become ideas that float in the current climate. Flexible and mobile, they constitute a diffuse imagination supported by fluid, tolerant networks and are often reinforced by their success in the media and by the interest they arouse in others. They speak to an isolated distraction, a latent question or a relationship incentive. In that case, the others who believe represent the authority (M. de Certeau, 1981: 374). This explains why opinion polls are conducted and confident witnesses are presented in the media. It is a specific procedure that makes it known that others believe, that they have positive views on the existence of the beyond. There is also allegorical expression, for example the beauty of nature as a sign of something else, something "more". Based on prior trust in a religious authority, this allegory can trigger new trust in the orthodoxy of an institution.

\section{Telling one's beliefs}

Responding to the researcher: "Yes, I believe that Jesus Christ is the son of God" does not amount to conviction. It is the conveying of an "opinion" or "piece of information" - in this case about one's own religious ideas. It appears that the phrase itself can constitute a bad model for conceiving belief: it is based on the association of "precise verbal expression to convictions that lack the hard edges verbalization endows them with" (D. Dennett, 1987: 21). But at the same time, the positive answer clearly shows that the interviewee thinks various realities (God, the resurrection) really exist. Believing is not just playing along for the duration of a book or film. It is also retaining the thought after the religious celebration is over and, possibly, expressing it to the anthropologist.

The responses and comments that the believer offers the anthropologist do not make the meaning of his or her beliefs clear. Their distinctive features must therefore be identified. They will help us to understand the management of religious statements in real life. With this in mind, I have questioned Catholics about the idea of resurrection, not to get them to give me the key to their beliefs, but to discover the ways in which they link belief statements together. The interview imposes a certain bias since they are asked for "information" on life after death and the resurrection. It is up to them to respond and make a series of statements. 
So what do we find? The responses revolve around the idea of a spiritual life after earthly life, and this possibility is presented as a "mystery" that is capable of uniting the spirits of all people and creating a world of "peace and light". Spiritual life is described as a state of "love to the highest degree": it is to live "in God's love". The foundations of the possibility of this spiritual life are the qualities of God: "he is infinitely powerful and he will offer us something unexpected"; "he is someone good fighting to destroy evil. This absence of evil is impossible in this world. There is a future for humanity beyond our way of thinking and our space"; "I have strong faith in the goodness of a God who creates, and real happiness means penetrating beyond death"; "God loves people to the point that he can do all...”.

The terms used to suggest this spiritual life (love, peace, happiness, ...) are polysemic and vague. Most often, there is an explicit refusal to imagine and describe what lies beyond death: "I'm not trying to imagine it. You shouldn't try to find it in a human model"; "I don't really have a conception". Based on their certainty that "another" world exists, its qualities can be a matter of indifference: "maybe it's bad, but I don't care"; "I admit it's not something I'm worried about".

When respondents give more precise information about this other world, one of the recurring characteristics of their mode of expression is the presence of mental restrictions that modalize and even deny the described quality: "The resurrection of Christ means something, but I don't understand it"; "I think there's something there, maybe"; "I believe in the communion of saints. But no one ever said anything about it". In fact, modalizing in this way has just as much of an impact on the metaphorical interpretation of the other world as it does on the literal interpretation. It is as if both interpretations could not be pursued to their conclusion. Thus, the metaphorical version is sometimes strongly expressed in a way that would appear to deny post-mortem resurrection: "The resurrection means that dead people are still around, even today; in the sense that I'm talking about them. What we experienced together left traces that still affect me. The resurrection means that the link existing between us is stronger than death". But this sort of interpretation comes to a halt as soon as it runs up against "trust in God", and the respondent recognises the inadequacy of words to explain it: "We have no images to describe it. It's a bit like if a blind person had to describe the world. But I believe that those who have passed away will be in a position to explain it to us". So there is "something"...

It is important to stress that mental restrictions also affect the literalist interpretation that Catholics use to express the idea of the resurrection of the body and of being reunited with loved ones in a specific place. Several types of modalization can be identified:

- Incomprehension, or at least the professed inability to know: "It's an open question. Christ said nothing explicit on the subject. I'm no intellectual myself"; 
"on the resurrection scenario, nothing can be said"; "Personally, I've never delved into those questions. I had seminary friends who did, but they all let it drop"; "I don't understand".

- Doubt tinged with hope: "I think there's something, maybe. I hope so".

- Irony usually expressed through laughter, in response to the request for a description of the resurrection, particularly in relation to being personally reunited with loved ones.

- The rejection of one's own past belief: "I used to believe in the physical resurrection. But now I'm less categorical".

- The appeal to theological knowledge: "In Jewish anthropology, the resurrection of the flesh does not mean the resuscitation of the dead."

There are also denials - sometimes adamant - of the literalist interpretation of the resurrection: "That's one part of the creed I'm sceptical about. I don't believe in the resurrection in the flesh"; "the way it works isn't that bones are taken out to put a guy back together. Heaven can't be conceived in terms of astrophysics"; "I struggle with the idea that the resurrection is a resuscitation of corpses". At most, these literalist images can be pedagogical means of reassurance: "one of our children became very distressed about death. He was completely reassured the night I told him that there is a place where we all find each other, and that existing links are not broken. You know, the hackneyed image".

But these denials, like the metaphorical interpretation and the literalist version, are not pursued to their conclusion because they are positively re-formed to connect with ideas of love and spiritual happiness, which make it possible to reconnect with the hope of reuniting with loved ones and maintaining interpersonal bonds after death. We are therefore witnessing a process that distinguishes between what life after death can and cannot be. These are the most frequent statements: "There can be no resurrection without the communion of saints. I often wonder how I'll find my father. I can't imagine him without his caresses, the look in his eye. He expressed so many things through caresses with the backs of his fingernails. I believe I'll find him. Not his fingernails but his heart and his tenderness"; "I don't think we'll be any different. Except for our bodies"; "people's faults will be gone. I think that with my husband, I'll no longer have a husband-wife relationship, but we'll still have a special bond"; "God placed within us relationships and connections that make us who we are. He's not going to demolish what he put into us. So we'll rediscover these connections after death. We won't find ourselves sitting together side-by-side, with reassembled families and people who recognise each other. The relationship will have a more spiritual form, love will be the essential thing"; “The resurrection doesn't mean leaving the tomb; I don't see billions of people resuscitated with their bodies but I believe there will be a dimension that goes beyond myself, my abilities. It is something exceptional within God's love, with all other people. There is no loss of humanity. We will all be there"; "I'm sure I'll find them; I won't recognise them but I'll 
see them through the resurrected Christ. My faith makes me believe that there is something eternal in everyone", "I know I'm destined to exist in God. It's so amazing that those dearest to us can never be absent. That's the highest degree of love. But I don't know if our loved ones will see us. Christ wasn't recognised".

These are various modalities used by Catholics when they speak about death and the resurrection - that is, how they deal with a set of signifiers (containers) about which there is no strict agreement on the corresponding signifieds (or contents):

- the maintenance of the division between a material world and a spiritual world whose possible existence one believes in;

- irony in relation to the idea that there is no guaranteed content and that most people seek content or keep content in their heads;

- the rejection of the notion of resuscitated bodies;

- taking the question seriously, while expressing regret about the uncertainty of the answers;

- dual language, which involves speaking in one way with some people, another way with others (at a public meeting: "no, the resurrection is not the resuscitation of dead people", behind the scenes (it was a dinner): "I can't do away with the image of Christ leaving the tomb", then making fun of yourself for this admitted contradiction; also the dual language of irony (or dismissiveness) behind the scenes and liturgical assertions in public;

- the institutional authority of the priest, sometimes applied in liturgies, sometimes reasserted during discussions (as opposed to self-disqualifying attitudes);

- the simultaneous assertion: on the one hand, that representations have limitations when applied to transcendent and inexpressible realities and, on the other hand, that these are a pedagogical necessity;

- the logic of uncertainty, that is, a dialectical logic that expresses, in different ways, the life and non-life of the dead (it isn't material but it's real; it's not about physically finding the people we've loved, but it's...);

- the idea that an answer to questions about content is not important, the implication being that the religious lies elsewhere.

Believers seem to be torn between literalist discourse of the kind that church discourse never really escapes - and which in any case retains ambiguity (with the notions of "real presence", "transubstantiation", ...) - and their desire to be in God's presence. On the one hand, there is "belief" in the materiality of resurrected life, which they do not want to believe in... and at the same time they give the impression that they don't dare not believe in it, or at the very least that they believe that they believe in the beyond. On the other hand there is love: the simple desire to love, to express love and to be in the presence of the loved person... perhaps in hope of "something" more. Hence the almost infinite mental restrictions. 
Metaphorical sentences are literally false. Believing cannot consist in approaching religious statements as metaphors, i.e. as literally false. Believers do not perceive these statements as literally true, but they do not consider them literally false either. This is their extraordinary specificity. The act of believing is part of this uncertain oscillation: "It's not literal, so is it a metaphor? No. But neither can it really be literal... without consequently being a metaphor”. Believers perceive religious statements as neither realistic, associated with a reference and a precise reality, nor as unrealistic, without any referential counterpart. Believing consists in referring to religious statements, thinking or feeling that they are not metaphorical expressions, but not really accepting their contents literally. This oscillation, this hesitation and this mental interspace are fascinating. They make up the act of believing. This does not mean that there are not occasional moments when believers make more distinct claims to doubt or certainty, when they keep their acceptance or their modulation in the background, as we will see. But to believe is to enter into this oscillation.

This is a crucial point. As we will discover, the rules governing the links between belief statements show that every answer given is part of a constantly rebounding movement, in the course of which each statement gives way to the next while constituting a critical axis relative to the previous one. This is what happens in practice: a movement of reversal and perpetual hesitation between various conceptions of the resurrection of the dead: it's literal, no it's not literal, it's symbolic; no it's not symbolic, it's more than that; no it's not literal, but it's...; and so on. This proceeds according to a movement that asserts, that denies, that questions the relevance of one point of view or another. Because how is one to state that paradoxical proposition "Jesus, son of God, dead and alive...", which would be hard for anyone to understand, other than through this game of reversals, hesitations and juxtapositions between contradictory points of view?

\section{Acts of believing}

There are other situations in which semi-propositional statements are spoken, recited or chanted. In religious ceremonies, many assertions like "Jesus lives" are made, often in association with declarations of love or fidelity, or with expressions of praise. They are devices for establishing co-presence with the absent, who is made present in the statement through the aforesaid declaration or through every entity (object, icon, holy bread) that represents the being in question (A. Piette, 1999; M. Finch, 2009). The presence of the divine being also reflects specific interlocutory relationships in which the absent addressee is explicitly solicited to enter the situation using a variety of linguistic and gestural forms. Just as internal dialogue is a way of preserving the presence of an absent person, prayer or declarations of love are specific techniques for remaining in the presence of the divine being. The intelligibility of these statements cannot depend on the presence of the being to which they are addressed. 
From this point of view, semi-propositional statements constitute possible points of departure - within a specific spatial-temporal situation - in a process of emotional evocation which activates the presence of the absent being in a variety of ways. We know that no ritual necessarily implies, by virtue of its performance, a mental attitude that corresponds with it perfectly, and implies even less an unproblematic adherence to any explicit or implicit meaning of the rite. Bourdieu often states that rituals are performed because "that's what is done" or "it has to be done" and one has no choice but to do it, without needing to know what the rituals mean (P. Bourdieu, 1992 [1981]: 18). But if, like Bourdieu, one moves the act of believing away from mental representations in order to make it a product of sub-verbal and sub-conscious dispositions, this leaves no room for analysing forms of adherence and the experience of human beings in the process of believing, or more specifically the believers' modes of interactional presence. It is a "dispositionalist" reading of the act of believing. The co-presence of men and gods, inserted into a particular context, according to specific circumstances, and mediated by objects, can take on different expressions. It can also appear outside of collective contexts. In any case it is a temporary meeting between a prevailing semi-propositional representation and an emotional disposition or intellectual process proper to the individual who is present in the situation (J. Bazin, 1991). I would say that this momentary encounter is a state of belief, more specifically an act of believing. Here is a non-exhaustive list of modalities of the act of believing:

- Addressing the supernatural being. A man and woman are in front of a closed chapel containing a Virgin Mary; the man removes his hat; they both mumble a few prayers for two or three minutes before leaving. Here there would be a "state of body" to borrow Bourdieu's term, a "bodily hexis" and a "linguistic habitus" in a way that would seem self-evident, but I would add that it is only a temporary state. They are in a state of half belief.

- Personal presence. Alone alongside other worshippers during a ceremony, a young man weeps during the story of the Last Supper and the transformation of bread and wine into the body and blood of Christ. The semi-propositional content of the priest's statement invites the man, in accordance with his own interpretation and his personal evocation, to experience "transubstantiation". He really believes that Jesus is present.

- Directed vision. This is the individual who, in a particular state of grace, sees the supernatural being (Jesus, the Virgin Mary...), which he or she can describe according to particular traits. This individual believes that the supernatural being really exists. Triggered by a particular emotional process, this "vision" is not independent on the content of prevailing semi-propositional representations.

- Link to an emotion. A man, convinced that the "final judgement" does not exist but conscious of having made a serious mistake, is haunted by fear of his fate to the point of asking a religious authority for forgiveness. Another, alone in a house in which a dead person lies, associates the slightest nocturnal sound 
with a manifestation of the dead person in a particular form. Even if he is convinced that ghosts do not exist, this type of emotional reaction connected with latent semi-propositional content (ghosts do exist) constitutes a state of belief, though certainly an ephemeral one. In these cases, the individuals believe $\mathrm{X}$ anyway. - Inevitable gesture. A person who, as mentioned above, slips personal mementos like photographs into a coffin before it is closed, to accompany the deceased. There is tension between the unshakeable need to preserve a connection with the deceased by means of the object and awareness of the pointlessness of this gesture (noting that he or she does not want this awareness to become too obvious). The person does not really believe X.

- Positive mental connection. The operation usually takes place outside the actual ritual. It enables the individual to mentally construct, from latent representations, the image of a situation that he or she either hopes for (being reunited with parents after death) or fears (the burning of his or her body in hell...). This type of connection can be associated with a deciphering of everyday events, in which the believer finds communicative "signs".

\section{Shifts}

A believer's everyday life is no doubt structured by the synchronisations that exist between him or herself and the supernatural being. Someone who genuinely and regularly believes is likely to produce frequent and positive mental connections, as will someone who really believed X. But it will also happen sometimes that this person believes $\mathrm{X}$ anyway, or that he or she does not really believe $\mathrm{X}$.

When analysing the real life "management" of religious statements, the ethnographer's attention is necessarily drawn to an element that I consider crucial: the principle of shifting from the moment when the individual enters into a state of belief (in which he or she "performs" an ephemeral act of believing) to the collapse of this state due to ordinary distractions and wandering thoughts, even scepticism and irony. This is what Paul Veyne calls "quotidian mediocrity": "[it] is precisely the result of this plurality, which in some states of neurotic scrupulosity is sensed as hypocrisy. We move endlessly from one program to another the way we change channels on the radio, but we do it without realizing it" (P. Veyne, 1988 [1983]: 86). From a 100\% possibility, there is a rapid drop to $5 \%$ or $0 \% \ldots$ Indifferent to inherent contradiction, the belief makes this flexibility all the easier, without in any way compromising the individual's sincerity.

One point should be stressed. Analysis of this real life "management" reveals that these statements are reconstituted outside of any act of believing, that is to say outside of belief situations, in so far as they are not affected by subsequent empirical refutations or by the absence of practical consequences. As Paul Veyne says, those who can positively connect with the semi-propositional content that places gods in the heavens would be astounded to see them in the sky, and it 
would be completely ridiculous if they hoped to see gods from the window of a plane. If a believer, having seen Jesus appear before him, went out in search of empirical evidence of the appearance, he or she would be abandoning the state of belief or act of believing. He or she would in fact be taking a positivist approach, as if incapable of imagining a world beyond the objective one. And if a man goes to his family tomb to introduce his newborn to deceased family members, does he really believe that they will be able to see the baby? "No", he would later say to someone who asked him about it. "But maybe a little", at the moment of the act, which is brief and cannot be fully thought through to its conclusion. Does the man know whether or not he believes? "Lethargic indifference", Veyne replies (P. Veyne, 1988 [1983]: 27), reminding us that people know very well what they should keep below the level of consciousness. These are instances of "eschatological inconsistency". They say a lot, not just about the relationships between belief statements (particularly about the beyond) and the incompletely pursued logical and/or practical consequences of the act of believing, but also about the relationship between specific behaviours and their corresponding mental attitudes. And none of this pertains to what might be termed weak faith.

Personal encounters with the divine being or positive mental connections can lead from one to the other and back again. In the course of a person's day, they are only limited, ephemeral moments. But the shifts away from these states of belief also have their own modalities, which can shed light on Veyne's remarks. Let us look at a few of them.

The most common is no doubt detachment between the state or act of belief and other situations into which the person can shift - what could be called the severance principle. A person who has a mental inspiration or positive mental connection in church about the semi-propositional content, according to which Jesus Christ was resurrected, forgets this content on Monday morning or indeed only a few minutes later.

A completely different context: when people read their horoscope (the appetite for optimistic information about the future, or fear of an unfavourable situation) constitute an ephemeral act of adherence to semi-propositional content. One possible reaction, stimulated by a minimal amount of critical thinking, is scepticism or even an ironic wink of the eye, right after reading the statement in question. As we have seen, for believers, this sort of irony and scepticism are just as likely to generate ironic or doubtful attitudes about the idea of being reunited with loved ones (M. Pelkmans, 2013).

Duality of attitude is another way of managing the shift out of a state of belief into another situation. To borrow Veyne's frequent example, when the worship of an emperor conforms to a religious model, the emperor is not considered a god. Romans believed that divinities lived in an alternative space and time, had no real biography and possessed mastery over the world and the future. 
Therefore they did not believe in the divinity of their emperor, even if they considered him extraordinary enough to grant him the highest honours. Despite occasional trembling, they proved that they were under no illusions because they did not address ex-votos to the emperor, whereas they did offer them to their own divinities.

Hesitation associated with distraction or indifference is another management technique, this time the management of the co-presence of acceptance and critical distance. A believer at church listening to the priest's words, who is looking at others standing and leaning, first hesitates, then enacts the ritual gesture, attempting to get into "sync", thinking that he or she has to get into it... like the others. Can we not relate this situation to the state of "pluralistic ignorance" in which participants can find themselves during a ceremony? Each of them, based on his or her own attitude - on a not entirely satisfying act of believing - keeps quiet about spiritual dissatisfaction, simulating an optimal experience (characteristically by getting caught up in the situation), thinking that everyone else is experiencing the moment perfectly and genuinely. These people, all of them thinking they are alone in lacking a relationship with God, can produce the same narrative of a successful experience and so go along with the crowd, each of them thinking he or she was the only one pretending... and so on (R. Stark, W. Bainbridge, 1985: 272-273).

At a higher level of consciousness than in the previous situations, the object of the act of believing (for example expecting the arrival of extra-terrestrial beings or hoping for the advent of an ideal ecological society) runs up against reality (they did not come, it was not realised). In this case the act of believing can, in different circumstances, morph into a firm conviction that is asserted, detailed, dogmatised and made the subject of a demand for respect.

Searching for proof is another way of effecting the shift from the state of belief to another situation. Depending on the mental attitude in question, it consists in searching for traces of a UFO landing, taking photos of the sky that could confirm the appearance of the divine being, developing physical theories to demonstrate the "ontological" reality of what people report in accounts of near-death experiences. It can also quite simply be a matter of reading the history of the life of Jesus or visiting landmarks of the beginnings of Christianity. These proofs do not only concern the credibility of witnesses, they are also about demonstrating the authenticity of the testimony, employing experimental approaches that are sometimes complex.

The very isolated moment of the state of belief is reflected in an array of everyday behaviours, attitudes and rules for living, for example in charitable acts. These behaviours, directly imputable to the intensity of a past act of believing or indirectly associated with an interest in one or another semi-propositional representation kept at the back of the mind, can also demonstrate a skill for deciphering signs in life's small events. 
The rhetorical use of the divine metaphor can take on different forms. It is used ironically, without any real comparison to the religious referent, such as when journalists or fans comment on the exploits of a football player. In "New Age" groups, divine appellations ("cosmic energy", "universal spirit") can be used as relevant metaphors, not so much for their underlying truth as for the dynamism, security and meaning they can bring. But this is just as possible with religious beliefs ${ }^{3}$.

\section{Conclusion: a theory of Homo religiosus}

No one says that Alice, the one who went to Wonderland, exists. The believer says that God exists. This almost mundane statement points to the specificity of divine beings and religious belief. In a way, if there were nothing but religions with various messages and gestures directed at God, one would almost be tempted to categorise gods as fictional characters. But unlike the latter, God continues to "exist" and to be present in various ways before and after the ritual, before and after the reading of a story. On the subject of divinities, people are quite capable of saying in all seriousness that they exist. Believing is not just playing along, doing the "done thing" during a ceremony, it's also attributing a non-fictional status to the divinity outside of the ceremony. This is the first "little more". But there is another one: underlying all social validations, transmission rationales and personal accounts, belief constitutes a private and mental experience. Believing means doing it and a little more. A strong characteristic of belief resides precisely in this "little more", several levels of which make up belief and particularly the believer: the reality, outside of the human world, of existences that are not confirmed and not confirmable; moments of co-presence with these entities a co-presence that is sensed or simply automatised; isolated moments of acceptance felt at the thought of these existences, or proclaimed acceptance; the dayto-day dynamics of this acceptance and co-presence. This particular "a little more" is crucial: actual sensed and felt moments of acceptance, their daily occurrence, their mental experience in real life. The act of believing as a moment of acceptance is this extra, and it is hard to reach. The social sciences, moreover, risk overlooking it, dissolving this moment into rituals, representations, statements or social rationales. But it is this risk that an anthropology of belief must avoid. At certain moments, individuals who trust the orthodoxy of the church can genuinely believe in the resurrection of Jesus. They can have positive mental connections with this semi-propositional content. At other moments they can be ironic about their attitude, or search for historical proof of the resurrection, or hesitate about how their belief should be formulated between metaphor and literalism.

3. Therefore it does not seem relevant to me to separate systems of representations (or of interactions), sometimes called "ontologies", from modalities of believing and adherence. 
After a critical process, they might retain only the core of church dogmas and only believe in the existence of God by means of positive mental connections. They may also believe either that Jesus was resurrected, or that he was not. A religious statement can also become a kind of floating idea disconnected from the church's authority. In this respect, the individual may believe $\mathrm{X}$ anyway, perhaps really believing, but also metaphorically adapting its formulation when speaking about it. In other cases, the idea can resonate through actions and interpretations of everyday events. This makes it possible to visualise a large number of combinations in the rectangle below.

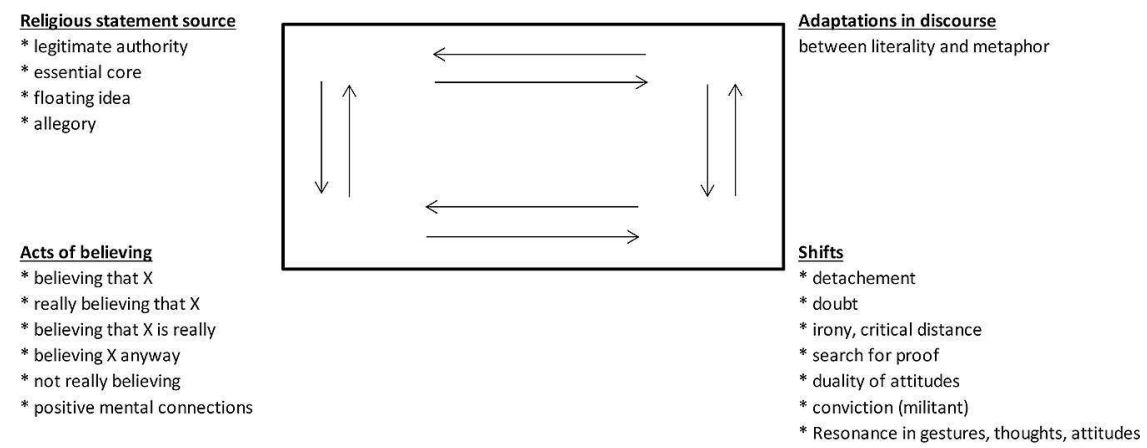

The difficult phenomenography of acts of believing requires that one looks at the subtle complexity that results from the interweaving between statements of belief, different modalities used for approving them (really believing, not believing, believing anyway) and the different forms of "shifting" (into distraction, scepticism, irony, the search for proof, detachment). Can these avenues be useful for exploring the modalities of belief? Fascinating comparisons between various religious worlds could be attempted on the basis of possible combinations of characteristics from each corner of the rectangle.

Michael Stausberg is right: theories of religion are often avoided by scholars of religion (M. Stausberg, 2010). But let us go a little further in concluding this article. With the idea of oscillation and hesitation, do we not have a principal characteristic of religious activity? What religious people experience seems to occur as if it were overshadowed by a message that said: "it's not that". Fiction? No, it's not that! Reality? No, it's not that! And so on... While the ritual is being performed, they communicate that it is not fiction; at the very moment when God becomes present, they say he is absent; at the very moment when people are bringing the divinity to life through their meditations, it is presented as an independent entity in relation to human beings. This play of negations is in fact central. Traditional definitions of religion then become questionable. Let us take a few examples. First, there are the definitions that concern how religious statements are received. I am thinking of the intellectualist school of leading British 
anthropologists from the past century, like Taylor or Frazer, who claimed that religion was an attempt to explain the world and nature rationally, and that for lack of data and knowledge, and through an error of reasoning, these explanations failed and were gradually replaced. All of this as if the gestures and statements in question literally meant what they did and said without any metaphorical impact, and as if individuals had no critical abilities... There are also interpretations that stress the nature of statements or practices, as in the case of symbolic interpretation, which sees these irrational figurations as nothing but symbolic expressions, metaphors that contain a hidden message that the anthropologist must find. This perspective is not much different from the idea of literal reception by people who lack critical abilities, and who are of course fooled by this metaphorical meaning. These types of interpretation err not only by analytically overlooking people's critical abilities, but also by characterising gods ambivalently. Thus they are positions on the nature of religion which are taken without an understanding of the people's opinions.

A third type of interpretation could also be mentioned, that which focuses on an actual definition of religion and more particularly on a specific mediation of the representation of the divine being. Here the danger is that religious activity will be defined and limited by a single feature. This could be the identification of god with a personification of society and with a visible manifestation of the communion of minds (É. Durkheim, 2008 [1912]). It could also be the association of religious activity with beliefs that are legitimised in reference to tradition (D. Hervieu-Léger, 2000 [1993]) or even, as is the case for a number of authors, in reference to a ritual and symbolic link with a "higher power". In each case, these definitions make a general characterisation of religion out of a localised element of discussion, out of a particular mediation, whereas in reality this element only exists and is only present in relation to and in dialogue with other elements to which they necessarily refer. Ethnographic fieldwork examining religious activity reveals this reflexive play of oscillation. It teaches us that the actors themselves are constantly asking questions.

Thus I would like to draw attention to the impact of negation in order to understand the existential reality of Homo religiosus. Passing in front of a positive pole, he is immediately driven to a negative pole according to a process of oscillation marked by back-and-forth movements and hesitation. Is the person acting as if there is a visible, tangible divine being before him? But he or she does not see the divinity and cannot touch it; it is even pointed out to him or her that the mediation is not really God, only a trace to which he or she should not become attached, and is told to keep on searching. Will our "believer" then start to think that there is "nothing at all", nothing real, only spectacle and fiction? But this fiction itself comes with the message that it is not really a fiction and that the divine being is represented by a diverse array of signs. This circulation can be seen in the following diagram: 


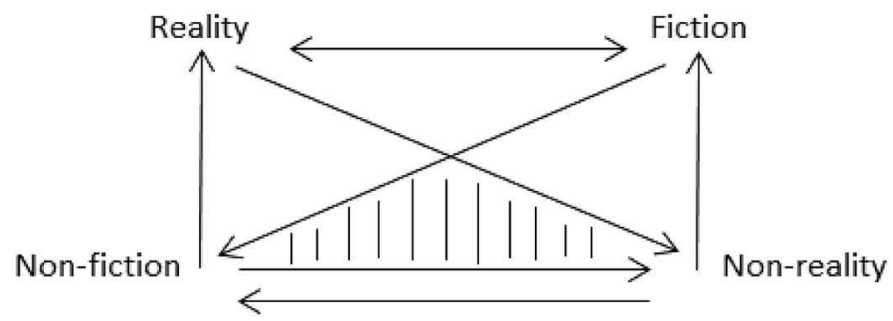

In religious activity, there is no direct, one-way path from fiction to reality (or vice versa) that would be the equivalent of saying: "It isn't fiction, it's real". This would be a positivist approach that consists in associating the divine being with a raw, objective fact and leaving it at that. In the other direction, it would be an atheistic approach, associating God with fiction: “it isn't real, it's fiction". There is, however, a semi-direct line that consists in starting from fiction, going towards non-fiction, then going down the endless path of representations (the left-hand vertical line), endless because it never arrives at reality (even if occasional stops are possible). A process that is more complicated - or at least more sceptical - consists in oscillating between non-reality, fiction and non-fiction (it's not a fiction but it's not real either). The striped zone, between the two negative poles (it's not spectacle, but it's not reality either), is no doubt strongly representative of ordinary religion. Even from there, it is possible to make excursions towards fiction without reaching it, or towards reality through the dismissal of endless representations.

Then what does religion in fact consist of? Representation and fiction? The construction of invisible beings and their presence? Hesitations and oscillations? This is a set of things that one can most certainly find in many other social activities. Then where is the characteristic aspect of religion to be found, if not in one or more of these elements? My answer: it is to be found in how they are placed in circulation by the play of negation. Religious existence thus finds itself in a permanent in-between. Humans, like gods, can only exist on the move, in oscillation, in a state of ambiguity. This is what an exploration of French Catholic beliefs and acts of believing enabled me to see. Comparisons between religions would be interesting to make.

Albert PIETTE Laboratoire d'ethnologie et de sociologie comparative Université Paris Ouest Nanterre La Défense piettealbert@hotmail.com 


\section{References}

BAzIN Jean, 1991, "Les fantômes de Mme du Deffand: exercices sur la croyance », Critique, XLVII, no 529-530, p. 492-511.

Bourdieu Pierre, 1992, The Logic of Practice, Richard Nice (transl.), Cambridge, Polity Press.

Boyer Pascal, 1994, The Naturalness of Religious Ideas. A Cognitive Theory of Religion, Berkeley, Los Angeles, Univ. of California Press.

CERTEAU Michel de, 1982, "Une pratique sociale de la différence: croire ", in Faire croire, Paris, École française de Rome, p. 363-383.

DennetT Daniel C., 1987, The Intentional Stance, Cambridge, the MIT Press.

Durkheim Émile, 2008 [1912], The Elementary forms of the Religious Life, Cladis M. S., Cosman C. (transl.), Oxford, Oxford Univ. Press.

Elster Jon, 1993, Political Psychology, Cambridge, Cambridge Univ. Press.

Finch Martha L., 2009, Dissenting Bodies. Corporealites in Early New England, New York, Columbia Univ. Press.

Hervieu-Léger Danièle, 2000 [1993], Religion as a Chain of Memory, Simon Lee (transl.), Cambridge, Polity Press.

LAMine Anne-Sophie, 2008, "Croyances et transcendances: variations en mode mineur ", Social Compass, 55 (2), p. 154-167.

LuCA Nathalie, 2013a, "L'effort d'y croire ", in K. Buffetrille, J.-L. Lambert, N. Luca, A. de Sales (éds), D'une anthropologie du chamanisme vers une anthropologie $d u$ croire, Paris, Études mongoles et sibériennes, centrasiatiques et tibétaines, p. 603-620.

-, 2013b, "L'entre-deux du temps du croire », Nouvelle revue de psychosociologie, 2-16, p. 17-35.

MAIR Jonathan, 2012, "Cultures of Belief", Anthropological Theory, 12-4, p. 448-466.

PelKmans Mathijs (ed.), 2013, Ethnographies of Doubt, faith and Uncertainty in Contemporary Societies, London, I.B. Tauris.

PIETTE Albert, 1999, La religion de près. L'activité religieuse en train de se faire, Paris, Metailie.

-, 2003, Le fait religieux. Une théorie de la religion ordinaire, Paris, Economica.

-, 2013, L'origine de la croyance, Paris, Berg international.

Ruel Malcom, 1982, "Christians Believers", in Religious Organization and Religious Experience, John Davis (ed.), London, Academic Press, p. 9-31.

Stausberg Michael, 2010, Prospects in Theories of Religion, Method and Theory in the Study of Religion, 22, p. 223-238.

SPERBER Dan, 1985 [1982], On Anthropological Knowledge: Three Essays, Cambridge, Cambridge Univ. Press.

STARK Rodney, Bainbridge William S., 1985, The Future of Religion, Berkeley, Univ. of California Press.

Veyne Paul, 1992 [1976], Bread and Circuses, Murray O., Pearce B. (transl.), London, Penguin Books.

-, 1988 [1983], Did the Greeks Believe in the Myths? Paula Wissing (transl.), Chicago, the Univ. of Chicago Press. 


\section{An Anthropology of Belief and a Theory of Homo Religiosus}

This article examines the modalities of belief on the basis of an ethnographic study of French Catholics. The author distinguishes the nature of religious statements, the modes of discourse people use to express their beliefs, and the personal modalities of acts of believing, which are isolated moments followed by various shifts into other activities, characterised by irony, doubt or detachment with regard to beliefs. The article concludes with a depiction of religious activity as a displacement, a hesitation, a perpetual oscillation between fiction and reality, believing and not believing, presence and absence.

Key words: believing, anthropology, Catholicism, religion, oscillation, hesitation, theory.

\section{L'anthropologie de la croyance et la théorie de l'homo religiosus}

Cet article examine les modalités de la croyance sur la base d'une étude ethnographique des catholiques français. L'auteur distingue la nature des déclarations religieuses, des modes de discours que les gens utilisent pour exprimer leurs convictions et des modalités personnelles d'actes de croire, qui sont des instants isolés suivis par divers passages à d'autres activités, avec ironie, doute ou détachement à l'égard des croyances. L'article conclut avec une représentation de l'activité religieuse comme un déplacement, une hésitation, une oscillation perpétuelle entre fiction et réalité, croyance et non croyance, présence et absence.

Mots-clés : croyance, anthropologie, catholicisme, religion, oscillation, hésitation, théorie.

\section{Antropología del creer y teoría del homo religiosus}

Este artículo examina las modalidades de las creencias sobre las bases de un estudio etnográfico de los católicos franceses. El autor distingue la naturaleza de las declaraciones religiosas, los modos del discurso que las personas usan para expresar sus creencias, y las modalidades personales de los actos del creer, que son momentos aislados seguidos por varios desplazamientos hacia otras actividades, con ironía, duda o desinterés en relación con las creencias. Este artículo concluye con una representación de la actividad religiosa como un desplazamiento, una vacilación, una perpetua oscilación entre ficción y realidad, creer y no creer, presencia y ausencia.

Palabras clave: creer, antropología, catolicismo, religión, oscilación, duda, teoría. 